\title{
Trade and Productivity Growth: Evidence From Vietnam's Manufacturing Sector at Provincial Level
}

\author{
Anh Ngoc Thi Ngo \\ Ho Chi Minh National Academy of Politics and Administration, Hanoi, Vietnam \\ Cuong Do-Tat \\ University of Canberra, Canberra, Australia \\ Ho Chi Minh National Academy of Politics and Administration, Hanoi, Vietnam
}

\begin{abstract}
Using a panel data at provincial level from 2004 to 2007 via mixing several officially statistical publications, the paper finds that the trade reform has affected significantly to the productivity of manufacturing sector among regions. Additionally, the transparency level of local government has positive effects on manufacturing sector productivity, while state sector biased has constrained the development of manufacturing sector. Moreover, the policy on development human capital of local government does not support the expansion of manufacturing firms.
\end{abstract}

Keywords: trade reform, manufacturing productivity, institutional performance, Vietnam

\section{Introduction}

"Doi moi" (renovation) policy implemented in 1986 is a new economic policy focusing on strengthening domestic firms, especially the manufacturing sector. Analogously, import-substitution and export-encouragement policies were considered to be the highest priority of Vietnamese government. As a consequence, the authorities employed a set of trade instruments following international standards such as tariffs, quotas and licenses (Auffret, 2003). In the next decades, after the implementation of "Doi moi", Vietnam involved in a wide range of bilateral and multilateral trade agreements such as ASEAN Free Trade Area framework (AFTA) in 1995 and the Vietnam-United States Bilateral Trade Agreement (VNUSBTA) in July 2001.

Vietnam applied to become a member of the World Trade Organization (WTO) in 1995, and became the 150th member of the WTO on January, 2007. This event benchmarked a significant step of trade liberalization in Vietnam with a further reduction in tariffs and elimination non-tariff barriers. Consequently, under the agreements of the WTO, local manufacturing firms have faced both opportunities and challenges.

There is a link between trade liberalization and manufacturing productivity. Chu and Kalirajan (2010) served us a useful summary about the linkage between trade liberalization and manufacturing productivity at the firm level in Vietnam. Their paper is the first study in exploring the relation. However, the connection of trade liberalization and manufacturing productivity at provincial level in Vietnam did not have much attention. There is

Anh Ngoc Thi Ngo, Master of Economics, Institute of Economics, Ho Chi Minh National Academy of Politics and Administration.

Cuong Do-Tat, Ph.D. candidate in Economics, University of Canberra; researcher at Institute of Economics, Ho Chi Minh National Academy of Politics and Administration. 
a gap in the literature. Effects of different practices of industrial policies at province level on manufacturing productivity at local areas have been the hot topic in Vietnam recently. Each province has its own advantages in developing a particular industry and how do local governments employ these advantages for supporting industry?

In order to answer the question, this assignment is organized as follow. The next part will provide a brief summary of some major references relate closely and directly to this essay. Based on the review of literature, methodology of the paper will be presented in the third part. A panel data at provincial level from 2004 to 2007 with more than 250 observations is summarized in the next part. The regression results at provincial level are served in the fifth section. Based on these findings, policy implications at local and central level are suggested in the sixth section. Finally, the conclusion is presented in the last part of the assignment.

\section{Literature Review}

\section{A Brief Review on Trade Liberalization}

Measuring trade liberalization is developed comprehensively by several generations of economists. Among them, the simplest way uses openness as a proxy for trade liberalization. Openness is calculated by the ratio of trade on GDP or trade indicators such as tariff or nontariff barriers, and reported in a large number of academic papers worldwide.

The fact that trade liberalization has contributed significantly to economic growth since 1950. Alesina and Wacziarg (1998) and Spolaore and Wacziarg (2005) confirm this issue in their papers. Edwards (1998) shows us a thoughtful paper on measuring the relation between trade liberalization and economic growth. He built up a sample of 93 countries and used nine variables proxy for trade liberalization. According to Edwards, eight out of nine variables had positive effect to TFP growth, while only one variable was reported negative effect. Ben-David (1993) reveal that among a sample of countries with open policy they were converging in terms of per capita income, while the group of close countries reported no evidence of convergence. Sachs and Warner (1995) confirm the result of Ben-David in their paper. Additionally, these authors found that open countries had 2 percent higher than close nations with the intention of annual rate of growth.

Using the new way of measuring trade liberalization, Alcalá and Ciccone (2004) review the relationship between trade liberalization and labor productivity at countries level. Employing a combination some dataset at country level such as Penn World Table and Statistics from IMF and new term "real openness", the two author assert that "in contrast to the marginally significant and non-robust effects of trade on productivity found previously, our estimates are highly significant and robust even when we include institutional quality and geographic factors in the empirical analysis" (Alcalá \& Ciccone, 2004).

\section{A Concise Assessment on Productivity}

In the mid 1970s, there were a considerable number of papers related to productivity measurement. Samuelson (1947) had opened up a new way of using production function to measure productivity. He used $f$ as a function that had maximum productivity, $Y$, which could be produced by a various ways of combining labor, $L$, and capital, $K$ at the time $t$, so $Y=f(L, K, t)$.

Solow (1957) employed production function in his study in order to show the determinant of capital in labor efficiency tendency. He assumes that the economy is perfect competition, and then we can derive production function as follow:

$$
\frac{d \ln f}{d t}=\frac{d \ln Y}{d t}-s_{L} \frac{d \ln L}{d t}-s_{K} \frac{d \ln K}{d t}
$$


where $s_{L}$ and $s_{K}$ are share of labor and capital respectively. Solow also demonstrates the relationship between the rates of labor productivity growth and capital-labor ratio and the multifactor productivity or total factor productivity (MFP or TFP):

$$
\frac{d \ln \left(\frac{Y}{L}\right)}{d t}=s_{K} \frac{d \ln \left(\frac{K}{L}\right)}{d t}+\frac{d \ln f}{d t}
$$

He recommends that MFP should be used to measure technical change rather than labor productivity. Afterward, Domar (1961), with more detailed data, suggested that industries and aggregated production function could be used in comparing industries productivity measures to cumulative quantifies. Jorgenson and Griliches (1967) supplied a method of constructing aggregated capital without a strong assumption on marginal products of unrelated assets. Diewert (1976) revealed that production function could be used with the purpose of measuring productivity by means of the least restrictive. Additionally, Tornqvist's (1936) index was employed commonly among production economists. Tornqvist's index is computed as following procedure. Firstly, the index figure calls $X$, can be calculated in the subsequent equation:

$$
\ln X_{t}-\ln X_{t-1}=\sum_{i}\left[s_{i}\left(\ln x_{i t}-\ln x_{i t-1}\right)\right]
$$

where $x_{i}$ stands for inputs, $s_{i}$ is the cost share weight. $s_{i}$ is computed by the below equation where $c_{i}$ is defined as unit cost of input.

$$
s_{i}=\frac{1}{2}\left\{\left[\frac{c_{i t} x_{i t}}{\sum_{i}\left(c_{i t} x_{i t}\right)}\right]+\left[\frac{c_{i t-1} x_{i t-1}}{\sum_{i}\left(c_{i t-1} x_{i t-1}\right)}\right]\right\}
$$

Tornqvist's (1936) index has been confirmed by a vast research paper that it has several significant properties. Diewert (1976) also concludes that Tornqvist's index is reliable with variety translog models of production function.

The latest development method of measuring productivity is stochastic frontier production function analysis. This way of computing is developed initially by Aigner, Lovell and Schmidt (1977) and Meeusen and van den Broeck (1977) independently. Battese and Coelli (1995) developed their idea and applied to panel data.

Index firms by $i=1,2, \ldots, n$, the stochastic production function is presented by:

$$
Y_{i t}=f\left(X_{i t}, \beta\right) e^{v_{i t}-u_{i t}}
$$

where, time $t=1,2, \ldots, T, Y_{i t}$ is output of firm $i$ at the time $t, X_{i t}$ a $(1 \times k)$ vector of inputs and $\beta$ a $(1 \times k)$ vector of parameters will be estimated. For cross-sectional data, the index of time certainly will be dropped. The error term $u_{i t}$ presents for firm technical inefficiency in manufacture and be measured by:

$$
u_{i t}=z_{i t} \delta+\omega_{i t}
$$

With $z_{i t}$ is a $(1 \times m)$ vector of descriptive variables, $\delta$ is $(m \times 1)$ vector of unknown parameters and $\omega_{i t}$ is a stochastic variable which guarantees that $u_{i t}$ will be a positive truncation of $N\left(z_{i t} \delta, \sigma_{u}^{2}\right)$. The state $u_{i t} \geq 0$ should be kept in order to guarantee all input variables stay on the stochastic production frontier.

The important property of stochastic frontier production function analysis is from the function we can compute the technical change of firm in the time line. Using this approach, we can link economic variables together in order to compute the relationship among them. For example, using stochastic frontier production function analysis, we can not only indicate the effect of inputs to output but also point out the efficiency of firm, and then the exogenous effect of other variable can be calculated.

\section{A Short Summary About the Linkage Between Trade Liberalization and Manufacturing Productivity}

An achievable link between trade liberalization and economic growth has attracted both economists worldwide and governments. More than 100 countries have been open their border in terms of trade 
liberalization since 1950 (Sachs \& Warner, 1995). Among them, some countries have opened their border intentionally, while the others have been attached to agreements with international policy conditions such as World Bank Structural Adjustment Loans. The rationale of such policies relies on the theoretical linkage between openness and economic growth. Greenaway, Morgan and Wright (2002) try to estimate the linkage between trade reform and economic growth in the short time period. They find significantly evidence supports their idea that trade liberalization boosts GDP per capita in a sample of up to 73 developing countries. Moreover, these researchers are successful in correcting the previous intellectuals who demonstrate the inconsistent results on this issue.

Chand and Sen (2002) use a panel data of 30 Indian industries in the period of time from 1973 to 1988 in order to calculate the relationship between trade liberalization and productivity of manufacturing in India. Based on several sensitive tests and regression analysis, the two researchers conclude that trade liberalization has had an affirmative linkage to the multi factor productivity growth in the Indian manufacturing sector. Moreover, Chand and Sen (2002) supply us a simple strategy with the purpose of testing hypothesis that "a rise in availability of specialized inputs raises TFP growth, and an illustration of use of a price wedge as an alternative measure of the extent of protection" (Chand \& Sen, 2002, p. 130). Supporting this result, Kalirajan and Bhide (2005), using a panel data of 7,800 Indian private firms, conclude that "On average, an increase in output of about 15 percent can be achieved by improving firms" efficiency through following best-practice technique, without having to increase any inputs or improve the existing technology (Kalirajan \& Bhide, 2005, p. 154). On the other hand, Balakrishnan, Pushpangadan and Babu (2000), using a panel data at firm level, conclude that in the post reform period there is no enhancement in Indian manufacturing sectors with respect of productivity growth, but they did not discuss reasons.

Chu and Kalirajan (2010), using a balanced panel data of 1,312 Vietnamese manufacturing firms in a period of 2000-2003, find a considerably evidence to support the theoretical literature that trade liberalization has positive effect on firms' performance. Employing stochastic frontier production function as major work-horse, the two researchers estimate the technical change and the effect of Vietnamese government's trade policy at the firm level. Interestingly, they find a radically result that trade liberalization has put Vietnamese manufacturing firms in front of the challenges and opportunities in the context of market economy. Chu and Kalirajan (2010) suggest that the key policy implication is about training. Vietnamese government should supply more incentives and supports for firms in terms of training their workers and more opportunities for potential workers of manufacturing sector to have suitable skill for meeting the conditions of employers.

\section{Methodology}

In order to investigate the relationship between trade liberalization and productivity of manufacturing sector at provincial level, this paper employs the Cobb-Douglas production form, following equation ${ }^{1}$, as a major workhorse:

where:

$$
Y_{i, t}=A_{i, t} K_{i, t}^{\alpha} L_{i, t}^{\beta} e^{\gamma l n\left(\text { open }_{i, t}\right)+\delta_{j} \text { institution }_{j, i, t}+\text { eregion }_{i}}
$$

$Y_{i, t}$ : the total turnover before tax of manufacturing firms at province $i$, in the time $t$;

$A_{i, t}$ : the technology level of manufacturing sector of province $i$, in the time $t$;

\footnotetext{
1 To construct the aggregate production function at provincial level, it is assumed that all manufacturing firms at the same province have no difference in the level of technology. Therefore, technology could be treated as constant in the model.
} 
$K_{i, t}$ : the total capital of manufacturing sector of province $i$, in the time $t$;

$L_{i, t}$ : the total labor of manufacturing sector of province $i$, in the time $t$;

$\ln \left(\right.$ open $\left._{i, t}\right)$ : the natural logarithm of the ratio of total export and import values to total output of province $i$, in the time $t$;

institution $_{j, i, t}$ : measurements of local government performance;

region $_{i}$ : proxy for other characteristics of regional effect;

$\alpha+\beta=1,0<\alpha, \beta<1$

$\gamma, \delta_{j}, \varphi$ : coefficients to capture the effects of openness, institutional performance and regional factor on output of manufacturing at provincial level;

$i=\overline{1, \ldots, 64}, j=\overline{1, \ldots, 5}, t=\overline{1, \ldots, 4}$.

To estimate the effects of variables on output of manufacturing sector at provincial level, the equation (1) has been taken log for both side and presented as below:

$$
\ln \left(Y_{i, t}\right)=\ln \left(A_{i, t}\right)+\alpha \ln \left(K_{i, t}\right)+\beta \ln \left(L_{i, t}\right)+\gamma \ln \left(\text { open }_{i, t}\right)+\delta_{j} \text { institution }_{i, j, t}+\text {. }_{\text {region }}
$$

The econometric model of the equation (2) can be presented as:

$$
\ln \left(Y_{i, t}\right)=\ln \left(A_{i, t}\right)+\alpha \ln \left(K_{i, t}\right)+\beta \ln \left(L_{i, t}\right)+\gamma \ln \left(\text { open }_{i, t}\right)+\delta_{j} \text { institution }_{i, j, t}+\text { pregion }_{i}+\varepsilon
$$

To test the constant return to scale, the restricted model of the equation (3) is:

$$
\ln \left(\frac{Y_{i, t}}{L_{i, t}}\right)=\ln \left(A_{i, t}\right)+\alpha \ln \left(\frac{K_{i, t}}{L_{i, t}}\right)+(\alpha+\beta-1) \ln \left(L_{i, t}\right)+\gamma \ln \left(\text { open }_{i, t}\right)+\delta_{j} \text { institution }_{i, j, t}+\text { oregion }_{i}+\varepsilon
$$

The value of $(\alpha+\beta-1)$ close to 0 is a considerably signal that the model has constant return to scale property.

\section{Data and Statistics Summary}

In this paper, three publications have been employed in order to construct the panel data of manufacturing sector at province level. The first publication is statistical yearbook of 64 provinces. These books have been used to have data on provincial outputs, export and import values. The second publication is a series statistical yearbook of industry. These books have been constructed based on the firms' survey from 2000 to 2008. These publications are used in order to have data on total turnover before tax, labors and capitals of manufacturing firms at province levels. The third publication is a series report on provincial competitive index of 64 provinces from 2004 to 2007. The surveys have been conducted by USAID and the Vietnam Chamber of Commerce and Industry (VCCI). The reports are used with the aim of having data on institutional performance at provincial level. These surveys have asked firms at 64 provinces about their ideas on the quality of local government and public policy relate to not only trade but also other policies.

$Y_{i, t}$ and $K_{i, t}$ have been calculated at constant price, 1994 price, to exclude the inflation effect and summarized in Table 1.

To calculate the openness, total import and export values have been exchanged from US dollar to Vietnamese dong and excluded the inflation by using price in 1994. The outputs of 64 provinces are in constant prices. Afterward, the openness is calculated by taking natural logarithm the ratio of total import and export to output as suggestion in the literature. The statistical summary of openness is provided in Table 2.

In the common sense of economic, the openness has been referred to a country as a whole, and in here, it does not aim to have an unusual variable. The using openness at provincial level aims to investigate the effect of learning knowledge via doing trade with oversea firms of local manufacturing firms. It should be more reasonable if we have just focused on the export and import of manufacturing sector rather than using a total value. However, the effects of export and import on manufacturing sector do not focus on the sector itself. The 
export and import of other sector have affected to manufacturing sector as well. Therefore, in this paper it used the ratio of total import and export to provincial outputs rather than emphasizing on manufacturing sector itself.

Table 1

A Statistical Summary of Firms' Turnover Before Tax, Capital and Labor

\begin{tabular}{llcccc}
\hline Variable & Observation & Mean & Standard error & Min & Max \\
\hline$Y_{i, t}$ & 256 & $16,084.29$ & $51,898.72$ & 37.47 & $533,681.9$ \\
$K_{i, t}$ & 256 & $6,707.288$ & $20,994.71$ & 16.9 & $217,647.8$ \\
$L_{i, t}$ & 256 & $50,615.91$ & $126,037.8$ & 619 & 912,425 \\
$\ln \left(Y_{i, t}\right)$ & 256 & 8.006866 & 1.804868 & 3.623541 & 13.18756 \\
$\ln \left(K_{i, t}\right)$ & 256 & 9.705522 & 1.401111 & 6.428105 & 13.72386 \\
$\ln \left(L_{i, t}\right)$ & 256 & 7.189728 & 1.693704 & 2.827314 & 12.29063 \\
$\ln \left(\frac{Y_{i, t}}{L_{i, t}}\right)$ & 256 & -1.698655 & 0.6809057 & -3.988116 & 0.83078 \\
$\ln \left(\frac{K_{i, t}}{L_{i, t}}\right)$ & 256 & -2.515794 & 0.6192219 & -4.0954 & 0.0322962 \\
\hline
\end{tabular}

Notes. $Y_{i, t}$ and $K_{i, t}$ are measured in billion dong; $L_{i, t}$ is measured in persons.

Table 2

The Statistical Summary of Openness

\begin{tabular}{llllll}
\hline Variable & Observation & Mean & Standard error & Min & Max \\
\hline openness & 248 & 0.945439 & 1.904777 & 0 & 13.89237 \\
$\ln \left(\right.$ open $\left._{i, t}\right)$ & 243 & -1.204425 & 1.798437 & -8.16164 & 2.63134 \\
\hline
\end{tabular}

To capture the effect of the performance of local government and the quality of public policy, this paper has employed the results from provincial competitive index project conducted by USAID and VCCI. The rationale of this selection is that this survey has been carried out for a various years and the target of these surveys is firms at 64 provinces. USAID and VCCI do not focus on manufacturing sector, but their sample has included the firms in the sector. Importantly, we might have an unbiased result because the surveys have obtained idea of not only manufacturing firms but also firms in other sectors. Therefore, the result might be more reliable and substantial.

To measure the institutional effect, this paper uses five indicators of the surveys, $(j=\overline{1, \ldots, 5})$, called:

$h c$ : stands for the concentration of local governments in improving human capital of their province. $h c$ has been measured in score with minimum is 0 and maximum is 10 , where 0 means lowest concentration on human capital improvement;

trans: stands for transparency and access to information, this variable has range from 0 to 10 with 0 means no transparency and access to information;

imple: stands for implementation and consistency of policies, this variable has scored from 0 to 10 , with 10 means highest implementation and consistency of policies;

info: presents for informal charges, this variable has scored from 0 to 10 , the score is 0 if firms have to pay more informal charges and their outcomes do not meet the requirement of firms;

$s s b$ : proxies for state sector bias, this variable has scored from 0 to 10 , the score is 0 if the provincial government has perfectly support to state sector firms and no support to private firms.

The statistical summary of these variables is in Table 3 . 
Table 3

Statistical Summary of Institutional Variables

\begin{tabular}{llllll}
\hline Variable & Observation & Mean & Standard error & Min & Max \\
\hline hc & 256 & 5.091211 & 1.61064 & 1 & 10 \\
trans & 256 & 5.555117 & 1.226776 & 2.15 & 8.68 \\
imple & 256 & 5.150742 & 1.218456 & 2.15 & 8.56 \\
info & 256 & 6.41875 & 0.7839583 & 3.38 & 8.85 \\
ssb & 256 & 6.57832 & 0.9573259 & 3.05 & 8.77 \\
\hline
\end{tabular}

Note. Source: Malesky (2005, 2006, 2007, 2008, 2009).

\section{Empirical Results}

To approximate the model, equation (3) and equation (4) and its various variations are estimated by using STATA MP Software version 11. The basic empirically result of the estimation has been summarized as follows.

Initially, the values of the two variables, $\ln (L)$ and $\ln (K)$, are statistically significant at $1 \%$. The results imply that the functional form chosen here works well with the dataset. The coefficient of $\ln (L)$ has the largest value when we estimate the baseline model, reported in the column (1) of Table 4. The result in column (1) shows us the situation that in Vietnam manufacturing sector relies much more on labor than on the capital. Additionally, when we put institutional variables into the model, reported in the column (2), the value of coefficient of $\ln (L)$ has been raised by 0.0387 , while the value of coefficient of $\ln (K)$ is reduced by 0.0279 . Therefore, the sum of $\alpha$ and $\beta$ raises from 1.166 to 1.178. This result implies an increasing return to scale rather than a constant return to scale. However, in the other estimations, reported in column (3) and column (5), the determinant of labor and capital on productivity is more equal than the previous two. The sum of $\alpha$ and $\beta$, 1.0753 and 1.0973, implies the constant return to scale of the model as suggestion in Solow's neo-classical model. Particularly, in the column (5), labor and capital have a quite similar determinant on productivity of manufacturing sector at provincial levels. This result is important in the case of Vietnam, because this means that there is no difference among provinces in terms of labor and capital due to the equally development policy of Vietnamese government. The results of all regressions are presented in Table 4.

Second, the five indexes of institutional variables are consistent with the models in terms of sign. In the four regressions, the policy of local government on development human capital is reported negatively with the local manufacturing sectors' productivity. This variable only is statistically significant in model (2) and model (3), while it is insignificant in model (4) and model (5). The negative sign of the variable implies that currently policy of local government is constraining the output of manufacturing firms. Consequently, policy implication is that local government should focus more on education and training.

The transparency and access information and state sector biased policies of local government are consistent with the models. All coefficients are almost statistically significant at $1 \%$. The sign of the transparency and access information is positive, while the sign of state sector biased is negative. This result implies that the more transparency and information availability, the higher productivity manufacturing sector has, whereas the more state sector biased the less productivity manufacturing gets. Additionally, this result has presented the currently hot topic in Vietnam that state own enterprises have strong support from Vietnamese government but their performance is lower than private firms' efficiency. The result indicates that one more point local governments have may lead to $10 \%$ increase in manufacturing productivity. 
Table 4

The Determinants of Manufacturing Sector's Output at Provincial Level

\begin{tabular}{|c|c|c|c|c|c|}
\hline \multirow{3}{*}{$\begin{array}{l}\text { Dependent variable } \\
\text { Independent variables }\end{array}$} & \multicolumn{5}{|c|}{ Natural log of manufacturing sector's output at provincial level } \\
\hline & \multicolumn{5}{|c|}{ Coefficients } \\
\hline & $(1)$ & $(2)$ & $(3)$ & $(4)$ & $(5)$ \\
\hline Constant & $\begin{array}{l}-2.441 * * * \\
(0.3215)\end{array}$ & $\begin{array}{l}-2.493 * * * \\
(0.4457)\end{array}$ & $\begin{array}{l}-0.3082 \\
(0.4550)\end{array}$ & $\begin{array}{l}-2.0629 * * * \\
(0.4978)\end{array}$ & $\begin{array}{l}-0.8714 \\
(0.5562)\end{array}$ \\
\hline $\operatorname{Ln}(\mathrm{L})$ & $\begin{array}{l}0.821 * * * \\
(0.0729)\end{array}$ & $\begin{array}{l}0.8597 * * * \\
(0.0683)\end{array}$ & $\begin{array}{l}0.6185^{* * *} \\
(0.0712)\end{array}$ & $\begin{array}{l}0.6989^{* * *} \\
(0.0693)\end{array}$ & $\begin{array}{l}0.5435^{* * *} \\
(0.0775)\end{array}$ \\
\hline $\operatorname{Ln}(\mathrm{K})$ & $\begin{array}{l}0.345^{* * * *} \\
(0.0631)\end{array}$ & $\begin{array}{l}0.3171^{* * *} \\
(0.0586)\end{array}$ & $\begin{array}{l}0.4568^{* * *} \\
(0.0559)\end{array}$ & $\begin{array}{l}0.4603 * * * \\
(0.0598)\end{array}$ & $\begin{array}{l}0.5538^{* * *} \\
(0.0621)\end{array}$ \\
\hline hc & & $\begin{array}{l}-0.0665^{* * * *} \\
(0.0231)\end{array}$ & $\begin{array}{l}-0.0438^{* *} \\
(0.0211)\end{array}$ & $\begin{array}{l}-0.0286 \\
(0.0207)\end{array}$ & $\begin{array}{l}-0.0256 \\
(0.0220)\end{array}$ \\
\hline $\operatorname{trans}$ & & $\begin{array}{l}0.1177^{* *} \\
(0.0478)\end{array}$ & $\begin{array}{l}0.1201^{* * * *} \\
(0.0349)\end{array}$ & $\begin{array}{l}0.1274 * * * \\
(0.0406)\end{array}$ & $\begin{array}{l}0.1039 * * * \\
(0.0372)\end{array}$ \\
\hline imple & & $\begin{array}{l}-0.0463 \\
(0.0441)\end{array}$ & $\begin{array}{l}-0.0659^{* *} \\
(0.0326)\end{array}$ & $\begin{array}{l}-0.0646^{*} \\
(0.0345)\end{array}$ & $\begin{array}{l}-0.0516 \\
(0.0338)\end{array}$ \\
\hline info & & $\begin{array}{l}0.1547^{* * * *} \\
(0.0466)\end{array}$ & $\begin{array}{c}0.0327 \\
(0.0414)\end{array}$ & $\begin{array}{c}0.0672 \\
(0.0434)\end{array}$ & $\begin{array}{c}0.0477 \\
(0.0426)\end{array}$ \\
\hline $\mathrm{ssb}$ & & $\begin{array}{l}-0.1814^{* * *} \\
(0.0421)\end{array}$ & $\begin{array}{l}-0.1014 * * * \\
(0.0349)\end{array}$ & $\begin{array}{l}-0.1110^{* * * *} \\
(0.0348)\end{array}$ & $\begin{array}{l}-0.0850^{* * *} \\
(0.0355)\end{array}$ \\
\hline Ln(openness) & & & & $\begin{array}{l}-0.5206^{* * * *} \\
(0.0768)\end{array}$ & $\begin{array}{l}-0.3044 * * * \\
(0.3392)\end{array}$ \\
\hline Ln(openness)*region 1 & & & & $\begin{array}{l}0.5586^{* * * *} \\
(0.0762)\end{array}$ & $\begin{array}{l}0.3392 * * * \\
(0.0999)\end{array}$ \\
\hline $\operatorname{Ln}($ openness)*region 2 & & & & $\begin{array}{l}0.6299 * * * \\
(0.0775)\end{array}$ & $\begin{array}{l}0.3698^{* * *} \\
(0.1093)\end{array}$ \\
\hline Ln(openness)*region3 & & & & $\begin{array}{l}0.6026^{* * * *} \\
(0.0735)\end{array}$ & $\begin{array}{l}0.4375^{* * *} \\
(0.1504)\end{array}$ \\
\hline Ln(openness)*region4 & & & & $\begin{array}{l}0.5772 * * * \\
(0.0867)\end{array}$ & $\begin{array}{c}0.0422 \\
(0.2203)\end{array}$ \\
\hline $\operatorname{Ln}($ openness)*region5 & & & & $\begin{array}{l}0.5115^{* * * *} \\
(0.0892)\end{array}$ & $\begin{array}{l}0.2808 * * \\
(0.1258)\end{array}$ \\
\hline Ln(openness)*region6 & & & & $\begin{array}{l}0.4659 * * * \\
(0.0751)\end{array}$ & $\begin{array}{c}0.1871^{*} \\
(0.1059)\end{array}$ \\
\hline $\operatorname{Ln}($ openness)*region7 & & & & $\begin{array}{l}0.3695^{* * *} \\
(0.0981)\end{array}$ & $\begin{array}{c}0.1159 \\
(0.1120)\end{array}$ \\
\hline region1 & & & $\begin{array}{l}-0.6562 * * * \\
(0.1045)\end{array}$ & & $\begin{array}{l}-0.3751^{*} \\
(0.1441)\end{array}$ \\
\hline region2 & & & $\begin{array}{l}-0.9781 * * * \\
(0.0996)\end{array}$ & & $\begin{array}{l}-0.5340^{* * *} \\
(0.1691)\end{array}$ \\
\hline region3 & & & $\begin{array}{l}-1.1804 * * * \\
(0.1475)\end{array}$ & & $\begin{array}{l}-0.3012 \\
(0.4569)\end{array}$ \\
\hline region4 & & & $\begin{array}{l}-0.8274 * * * \\
(0.1289)\end{array}$ & & $\begin{array}{l}-0.9381 * * * \\
(0.3361)\end{array}$ \\
\hline region5 & & & $\begin{array}{l}-0.7081 * * * \\
(0.1189)\end{array}$ & & $\begin{array}{l}-0.4128^{* * * *} \\
(0.1559)\end{array}$ \\
\hline region6 & & & $\begin{array}{l}-0.7803 * * * \\
(0.1253)\end{array}$ & & $\begin{array}{l}-0.6787 * * * \\
(0.1963)\end{array}$ \\
\hline region7 & & & $\begin{array}{l}-0.4778^{* * * *} \\
(0.1086)\end{array}$ & & $\begin{array}{l}-0.0549 \\
(0.1469)\end{array}$ \\
\hline Observations & 256 & 256 & 256 & 243 & 243 \\
\hline$R^{2}$ & 0.8974 & 0.9092 & & 0.9414 & \\
\hline $\mathrm{Adj}-R^{2}$ & & & 0.9370 & & 0.9426 \\
\hline
\end{tabular}

Notes. In (1), (2) and (4): robust standard errors are in parentheses; In (3) and (5): standard errors are in parentheses; ***, **, *: indicate coefficients are statistically in $1 \%, 5 \%$, and $10 \%$ respectively. Source: Author's estimation. 
Table 5

The Restricted Model Estimations

\begin{tabular}{|c|c|c|}
\hline \multirow{3}{*}{ Independent variables } & \multicolumn{2}{|c|}{ Natural logarithm of output per worker } \\
\hline & \multicolumn{2}{|c|}{ Coefficients } \\
\hline & (6) & (7) \\
\hline constant & $\begin{array}{l}-0.3082 \\
(0.4550)\end{array}$ & $\begin{array}{l}-0.8714 \\
(0.5563)\end{array}$ \\
\hline $\operatorname{Ln}(\mathrm{K} / \mathrm{L})$ & $\begin{array}{l}0.4567 * * * \\
(0.0559)\end{array}$ & $\begin{array}{l}0.5539^{* * *} \\
(0.0621)\end{array}$ \\
\hline $\operatorname{Ln}(\mathrm{L})$ & $\begin{array}{l}0.0753 * * \\
(0.0311)\end{array}$ & $\begin{array}{l}0.0973^{* *} \\
(0.0397)\end{array}$ \\
\hline hc & $\begin{array}{l}-0.0438^{* *} \\
(0.0211)\end{array}$ & $\begin{array}{l}-0.0256 \\
(0.0220)\end{array}$ \\
\hline trans & $\begin{array}{l}0.1201 * * * \\
(0.0349)\end{array}$ & $\begin{array}{l}0.1039^{* * *} \\
(0.0372)\end{array}$ \\
\hline imple & $\begin{array}{l}-0.0659 * * \\
(0.0326)\end{array}$ & $\begin{array}{l}-0.0516 \\
(0.0338)\end{array}$ \\
\hline info & $\begin{array}{c}0.0327 \\
(0.0414)\end{array}$ & $\begin{array}{c}0.0477 \\
(0.0426)\end{array}$ \\
\hline ssb & $\begin{array}{l}-0.1014 * * * \\
(0.0349)\end{array}$ & $\begin{array}{l}-0.0850^{* *} \\
(0.0355)\end{array}$ \\
\hline Ln(openness) & & $\begin{array}{l}-0.3044^{* * *} \\
(0.0966)\end{array}$ \\
\hline Ln(openness)*region1 & & $\begin{array}{l}0.3392^{* * * *} \\
(0.0999)\end{array}$ \\
\hline $\operatorname{Ln}($ openness) $*$ region 2 & & $\begin{array}{l}0.3698^{* * *} \\
(0.1093)\end{array}$ \\
\hline Ln(openness)*region3 & & $\begin{array}{l}0.4375^{* * * *} \\
(0.1504)\end{array}$ \\
\hline $\operatorname{Ln}($ openness) $*$ region 4 & & $\begin{array}{c}0.0422 \\
(0.2204)\end{array}$ \\
\hline Ln(openness)*region5 & & $\begin{array}{l}0.2808^{* *} \\
(0.1258)\end{array}$ \\
\hline $\operatorname{Ln}($ openness $) *$ region6 & & $\begin{array}{c}0.1871^{*} \\
(0.1059)\end{array}$ \\
\hline Ln(openness)*region7 & & $\begin{array}{c}0.1159 \\
(0.1120)\end{array}$ \\
\hline region1 & $\begin{array}{l}-0.6562 * * * \\
(0.1044)\end{array}$ & $\begin{array}{l}-0.3752^{*} \\
(0.1441)\end{array}$ \\
\hline region2 & $\begin{array}{l}-0.9781^{* * *} \\
(0.0996)\end{array}$ & $\begin{array}{l}-0.5340^{* * *} \\
(0.1691)\end{array}$ \\
\hline region3 & $\begin{array}{l}-1.1805^{* * *} \\
(0.1476)\end{array}$ & $\begin{array}{l}-0.3012 \\
(0.4569)\end{array}$ \\
\hline region4 & $\begin{array}{l}-0.8273^{* * *} \\
(0.1289)\end{array}$ & $\begin{array}{l}-0.9381 * * * \\
(0.3361)\end{array}$ \\
\hline region5 & $\begin{array}{l}-0.7081^{* * *} \\
(0.1188)\end{array}$ & $\begin{array}{l}-0.4127 * * * \\
(0.1559)\end{array}$ \\
\hline region6 & $\begin{array}{l}-0.7802 * * * \\
(0.1253)\end{array}$ & $\begin{array}{l}-0.6786^{* * *} \\
(0.1963)\end{array}$ \\
\hline region7 & $\begin{array}{l}-0.4778^{* * *} \\
(0.1086)\end{array}$ & $\begin{array}{c}-0.0549 \\
(0.1469)\end{array}$ \\
\hline Observation & 256 & 243 \\
\hline $\operatorname{Adj}-R^{2}$ & 0.5572 & 0.5859 \\
\hline
\end{tabular}

Notes. ${ }^{* * *}$,** and *: statistically significant at $1 \%, 5 \%$ and $10 \%$ respectively; Standard errors are in parentheses. Source: Author's estimation.

The implementing and consistency in public policies and informal charge are not well statistically defined but their signs are consistent in the models. The negative sign of implementing and consistency of policies 
reflect the reality of economic policies in Vietnam. In fact, the inconsistency of policies at local and central level is currently constraining the improvement of the manufacturing sector and the other sectors. Firms have to face the prompt change of policies and the changing has affected considerably on firms' strategy. On the other hand, the informal charge relates to the situation that the firms have obtained unofficial information from authorities and then they have suitable strategy to get benefit. The coefficient of this variable is almost statistically insignificant but the positive sign implies the situation mentioned above. Actually, in the context of Vietnam, having information in unofficially way is the major strategy of a large number of firms. As a consequence, the corruption has been seen a permanent problem of Vietnamese government system and it is difficult to wipe out.

Third, in general trade in Vietnam has negative effect to manufacturing sectors' productivity at provincial levels. Vietnam's manufacturing firms do not have strong competitive power to import products. The significant evidence for this result is the invasion of Chinese products in the markets. However, deeper sight into regions has a different picture. Trade in the regions of the North side of Vietnam (region 1, region 2, region 3 and region 4) have positive effect on manufacturing sectors productivity, while the regions of the South side of Vietnam have negative effect ${ }^{2}$. This result implies that there is different effect in terms of geography. Employing dummy variables locating the region of the province in the model shows us that provincial conditions do not have different effect on manufacturing sectors' productivity.

The restricted model is built up by estimating equation (4). The results of these estimations have presented in Table 5. The coefficients of $\ln (L)$ in both models are statistically significant at $5 \%$, but the values close to 0 . Therefore, we can conclude that this model may satisfy the assumptions of Solow's neo-classical model of constant return to scale. The other coefficients are identical with above models' empirical results, but the standard errors are smaller. Additionally, the adjusted $R^{2}$ in restricted models are slighter than unrestricted model.

\section{Policy Implications}

In this part, policy implications of empirical analysis have been discussed briefly in order to point out some suggestions for the local and the central government.

First, the Vietnamese government should focus on renovating the education system, especially vocational training for low skill labors. Presently, the policy of the government on development of human capital has constrained manufacturing sector's productivity growth. Lack of concentration on vocational training has brought about the situation that employees do not meet the demand of employers. Chu and Kalirajan (2010) find strong evidence that higher skill labors increase significantly firms technical efficiency. Their finding is an important confirmation for considering the policy aim to improve currently the vocational training system in Vietnam. Moreover, the finding of this paper implies that the performance of the vocational training centers, located on almost 64 provinces, is poor. They cannot meet the requirement of manufacturing firms in terms of supplying skilled labors. In addition, they cannot facilitate trainees' necessary skills. Therefore, the government should examine vocational training centers carefully in order to find effective solutions for this issue.

Second, trade reform has affected to manufacturing sector differently among regions. This situation implies that some regions have benefited from trade reform of government, while the others do not have any advantages. It will lead to the gap among regions. Advantaged regions in terms of favor trade will become

\footnotetext{
${ }^{2}$ For example, trade of a province in region 1 will affect to productivity of manufacturing sector an amount of $-0.5206+0.5586=$ 0.038 , and a province in region 7 will have $-0.5206+0.3695=-0.1511$.
} 
richer, while disadvantaged regions will become poorer and then the gap between them will be widened in over time. The robust evidence on this issue of the above models implies that the government should have a system of policies to balance the development between regions.

Third, transparency and access information has positive and robust effect on the manufacturing sector, so the policy implication is that the government should increase level of transparency and availability of information. Internet should be seen as a major instrument. Transparency is very important for developing countries where the communication between firms and government is weak. Increasing transparency implies more rights to access information for firms itself and more chances to communicate between firms and authorities. Moreover, increasing transparency will reduce the amount of money spending on informal connections and will avoid the corruption.

Finally, the government should run an equal market for both state-owned and private firms. It means that the state-owned and the private firms have the same chance to access the credit and joint in large projects. Actually, a lot of large projects in Vietnam have been kept for state-owned firms without consideration on performance. This action constrains the development of the private manufacturing firms and reduces the productivity of the manufacturing sector.

\section{Conclusion}

This paper has analyzed the fact of the manufacturing sector in Vietnam at provincial level to point out constrains and favors in this sector. Using a panel data at provincial level from 2004 to 2007 via mixing several official statistical publications, the paper finds that the trade reform has affected differently across regions. Moreover, the level of transparency of the local government has positive effect on the manufacturing sector's productivity, while the state sector biased has constrained the development of manufacturing sector. Additionally, the policy in development human capital of the local government does not support the expansion of the manufacturing firms.

\section{References}

Aigner, D., Lovell, C., \& Schmidt, P. (1977). Formulation and estimation of stochastic frontier production function models. Journal of Econometrics, 6(1), 21-37.

Alcalá, F., \& Ciccone, A. (2004). Trade and productivity. Quarterly Journal of Economics, 119(2), 613-646.

Alesina, A., Spolaore, E., \& Wacziarg, R. (2005). Trade, growth and the size of countries. In P. Aghion, \& S. N. Durlauf (Eds.), Handbook of economic growth, 1B, 1499-1542, Elsevier.

Athukorala, P. (2006). Trade policy reforms and the structure of protection in Vietnam. The World Economy, 29(2), 161-187.

Auffret, P. (2003). Trade reform in Vietnam: Opportunities with emerging challenges. World Bank Publications.

Balakrishnan, P., Pushpangadan, K., \& Babu, M. (2000). Trade liberalization and productivity growth in manufacturing: Evidence from firm-level panel data. Economic and Political Weekly, 35(41), 3679-3682.

Battese, G., \& Coelli, T. (1995). A model for technical inefficiency effects in a stochastic frontier production function for panel data. Empirical Economics, 20(2), 325-332.

Ben-David, D. (1993). Equalizing exchange: Trade liberalization and income convergence. The Quarterly Journal of Economics, $108(3), 653-679$.

Chand, S., \& Sen, K. (2002). Trade liberalization and productivity growth: Evidence from Indian manufacturing. Review of Development Economics, 6(1), 120-132.

Chu, S., \& Kalirajan, K. (2010). Impact of trade liberalization on technical efficiency of Vietnamese manufacturing firms. In Frontier issues in technology, development and environment.

Coelli, T. J., Rao, D. S. P., O’Donnell, C. J., \& Battese, G. E. (2005). An introduction to efficiency and productivity analysis (2nd ed.). New York: Springer. 
Dean, E., \& Harper, M. (2001). The BLS productivity measurement program. In C. Hulten, E. Dean, \& M. Harper (Eds.), New developments in productivity analysis. Chicago and London: University of Chicago Press, 55-84.

Diewert, W. (1976). Exact and superlative index numbers. Journal of Econometrics, 4(2), 115-145.

Domar, E. (1961). On the measurement of technical change. Economic Journal, 71(284), 710-729.

Edwards, S. (1998). Openness, productivity and growth: What do we really know? Economic Journal, 108(447), 383-398.

Greenaway, D., Morgan, W., \& Wright, P. (2002). Trade liberalization and growth in developing countries. Journal of Development Economics, 67, 229-244.

Gustafsson, P., \& Segerstrom, P. (2006). Trade liberalization and productivity growth (Unpublished manuscript).

Hulten, C., Dean, E., \& Harper, M. (Eds.) (2001). New developments in productivity analysis. Chicago and London: University of Chicago Press.

Jorgenson, D., \& Griliches, Z. (1967). The explanation of productivity change. The Review of Economic Studies, 34(3), $249-283$.

Kalirajan, K., \& Bhide, S. (2005). The post-reform performance of the manufacturing sector in India. Asian Economic Papers, 3(2), 126-157.

Kodde, D., \& Palm, F. (1986). Wald criteria for jointly testing equality and inequality restrictions. Econometrica: Journal of the Econometric Society, 1243-1248.

Kompas, T., Che, T., Nguyen, H., \& Nguyen, H. (2010). Productivity, net returns and efficiency: Land and market reform in Vietnamese rice production (Paper presented at the 2nd Vietnam Economic workshop).

Kong, X., Marks, R., \& Wan, G. (1999). Technical efficiency, technological change and total factor productivity growth in Chinese state-owned enterprises in the early 1990s'. Asian Economic Journal, 13(3), 267-282.

Malesky, E. (2005). The Vietnam provincial competitiveness index 2005: Measuring economic governance for private sector development. Hanoi, Vietnam: USAID \& VCCI.

Malesky, E. (2006). The Vietnam provincial competitiveness index 2006: Measuring economic governance for private sector development. Hanoi, Vietnam: USAID \& VCCI.

Malesky, E. (2007). The Vietnam provincial competitiveness index 2007: Measuring economic governance for private sector development. Hanoi, Vietnam: USAID \& VCCI.

Malesky, E. (2008). The Vietnam provincial competitiveness index 2008: Measuring economic governance for private sector development. Hanoi, Vietnam: USAID \& VCCI.

Malesky, E. (2009). The Vietnam provincial competitiveness index 2009: Measuring economic governance for private sector development. Hanoi, Vietnam: USAID \& VCCI.

Meeusen, W., \& van Den Broeck, J. (1977). Efficiency estimation from Cobb-Douglas production functions with composed error. International Economic Review, 18(2), 435-444.

Rodriguez, F., \& Rodrik, D. (1999). Trade policy and economic growth: A skeptic's guide to the cross-national evidence (NBER working paper, 7081).

Sachs, J., \& Warner, A. (1995). Economic reform and the process of global integration. Brookings Papers on Economic Activity, 1, $1-118$.

Samuelson, P. A. (1947). Foundations of economic analysis. Cambridge, MA: Harvard University Press.

Solow, R. (1957). Technical change and the aggregate production function. The Review of Economics and Statistics, 312-320.

Tornqvist, L. (1936). The Bank of Finland's Consumption Price Index. Bank of Finland Monthly Bulletin, 10, 1-8.

Wacziarg, R., \& Welch, K. (2008). Trade liberalization and growth: New evidence. The World Bank Economic Review. 